\title{
TESTICULAR TEMPERATURE IN THE SOUTHERN ELEPHANT SEAL, MIROUNGA LEONINA (LINN.)
}

\author{
M. M. BRYDEN
}

Antarctic Division, Department of External Affairs, Melbourne, Australia*

(Received 20th December 1966)

The testes of the Southern Elephant Seal are extra-abdominal, but each is contained in a separate inguinal pouch and not in a single scrotum; they lie beneath the blubber and against the muscles of the abdomen, and it would appear that their position is fixed as there is no evidence of a tunica dartos, and the rudimentary external cremaster muscle consists of a few weak fibres arising from the obliquus internus abdominis. The testicular temperature might therefore be expected to be close to the body temperature.

TABLE 1

COMPARISON BETWEEN THE RECTAL, ABDOMINAL AND TESTICULAR TEMPERATURES IN THE SOUTHERN ELEPHANT

SEAL

\begin{tabular}{c|c|c|c}
\hline Animal & $\begin{array}{c}\text { Rectal } \\
\text { temperature }\left({ }^{\circ} \mathrm{C}\right)\end{array}$ & $\begin{array}{c}\text { Abdominal } \\
\text { temperature }\left({ }^{\circ} \mathrm{C}\right)\end{array}$ & $\begin{array}{c}\text { Testicular } \\
\text { temperature }\left({ }^{\circ} \mathrm{C}\right)\end{array}$ \\
\hline $655 / 39$ & 36.0 & 36.5 & 30.6 \\
$65 / 40$ & 36.5 & 36.8 & $30 \cdot 1$ \\
\hline
\end{tabular}

Two mature bull elephant seals were immobilized with succinylcholine chloride (Ling \& Nicholls, 1963), and the temperature of the testes was measured by cutting through the blubber layer down to the testicular pouch and passing a thermistor probe approximately $4 \mathrm{~cm}$ into the testis, which represented approximately the centre of the testis. At the same time the rectal temperature was read with a mercury clinical thermometer, and approximately 2 min later, when the animal was killed, the temperature of the abdominal cavity in the hepatic region was read using a $15-\mathrm{cm}$ long thermistor probe. The temperatures recorded in this way are shown in Table 1.

Animal $65 / 39$ was measured 1 month before the onset of the breeding season and $65 / 40$ when breeding started.

It is seen that the temperature of the testis in this species is between 6 and $7^{\circ} \mathrm{C}$ lower than the rectal temperature and body cavity temperature. This temperature difference is slightly greater than that for the ram (Waites \& Moule, 1961). Hence the testes of the Southern Elephant Seal are maintained at a

* Postal address: Department of Animal Husbandry, University of Sydney, New South Wales, Australia. 
temperature several degrees below the temperature of the body cavity, and in this regard are similar to most mammals even though they do not have the benefit of scrotal thermoregulation. The means of maintaining the temperature of the testes below the temperature of the body cavity in these animals seems to be entirely a direct vascular heat exchange mechanism, shown to be present in the ram (Waites \& Moule, 1961) but having a secondary role in that species.

This work was carried out at Macquarie Island $\left(54^{\circ} \mathrm{S}, 159^{\circ} \mathrm{E}\right)$ as a part of the Australian National Antartic Research Expedition Biology programme, 1965.

\section{REFERENCES}

Ling, J. K. \& Nicholts, D. G. (1963) Immobilization of elephant seals using succinylcholine chloride. Nature, Lond. 200, 1021.

Waites, G. M. H. \& Moule, G. R. (1961) Relation of vascular heat exchange to temperature regulation in the testis of the ram. 7. Reprod. Fert. 2, 213. 